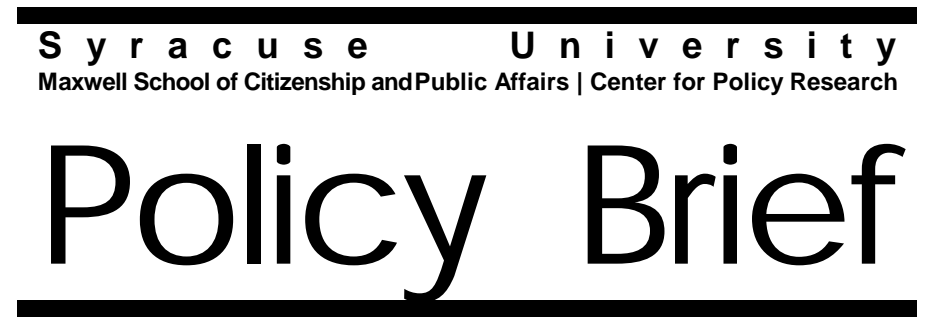

Financing Higher Standards in Public Education: The Importance of Accounting for Educational Costs

William Duncombe and John Yinger

No. $10 / 1998$ 
William Duncombe is Associate Professor of Public Administration, and Senior Research Associate, Center for Policy Research. He has published widely in the areas of school finance, school aid design, and educational costs and efficiency. John Yinger is Professor of Economics and Public Administration, and Associate Director for the Metropolitan Studies Program, Center for Policy Research. He is a specialist in state and local public finance, housing discrimination, and urban economics.

A version of this Policy Brief was presented at a conference sponsored by the Committee for Education Finance of the National Research Council, Irvine, California, January 1998. For a more detailed analysis see: Duncombe, Ruggiero, and Yinger 1996; Duncombe and Yinger forthcoming $b$; and Duncombe and Yinger 1997.

The Policy Brief series is a collection of essays on current public policy issues in aging, health, income security, metropolitan studies and related research done by or on behalf of the Center for Policy Research at the Maxwell School of Citizenship and Public Affairs.

Single copies of this publication may be obtained at no cost from the Center for Policy Research, Maxwell School, 426 Eggers Hall, Syracuse, NY 13244-1020, or from the CPR web site at www-cpr.maxwell.syr.edu.

(C) 1998, Syracuse University 


\section{Financing Higher Standards in Public Education: The Importance of Accounting for Educational Costs}

William Duncombe and John Yinger

Performance standards have been at the center of recent debates on educational reform. Many states have implemented new performance standards, often based on student test scores, and a district's state aid is sometimes linked to its success in meeting the standards. This focus on performance is designed primarily to promote better student achievement by holding schools accountable. However, a school's performance is influenced not only by the actions of its administrators and teachers but also by factors outside its control, such as the nature of its student body. A recent article in The New York Times expresses this concern very clearly. In a discussion of report cards and school rankings, now used in 35 states, this article points out that

because such rankings are often based exclusively on test scores, which give only a partial snapshot of a school's performance, some educators worry that schools may be unfairly blackballed, especially those with high populations of poor children (Steinberg 1998).

Thus, a focus on performance is inevitably unfair, especially to cities, unless it accounts for the impact on performance of factors outside the control of school officials. Otherwise, some schools get credit for favorable conditions that were not of their making and other schools get blamed for unfavorable conditions over which they have no control. To be fair, school report cards and performance-based state aid systems must distinguish between poor performance based on external factors and on school inefficiency. Many state aid systems have taken one step in this direction by compensating districts with low wealth, a factor over which they have no control. However, school district performance is also influenced by the cost of education, which varies widely from district to district based on local wage rates, student characteristics, and other external factors. Existing state aid formulas either ignore these 


\section{Metropolitan Studies Program Policy Brief}

factors altogether or else use ad hoc corrections, such as "weighted pupil" counts, that account for them partially at best.

The focus on student performance is consistent with the movement in state courts towards addressing deficiencies in educational "adequacy" rather than relative equity (Underwood 1995). According to Clune (1994, p. 377), "A social consensus now seems to be developing around high minimum achievement as the common goal for educational adequacy," and since 1989, several state courts have ruled that their state constitution guarantees students an adequate level of educational opportunity (Fuhrman, Elmore, and Massell 1993). The emphasis on adequacy in state education litigation magnifies the need to consider cost differences across districts.

In this policy brief, we explain why a performance focus and educational cost indexes must go hand in hand, discuss alternative methods for estimating educational cost indexes, and show how these costs indexes can be incorporated into a performance-based state aid program. We show, using data from New York State, that controlling for costs in the design of school aid formulas is crucial to enable central cities to reach educational adequacy standards.

\section{The Conceptual Foundations of Educational Cost Indexes}

An educational cost index is designed to measure how much a district would have to spend, relative to the average district, to obtain any given performance target. This section explains the relationship between performance measures and cost indexes, and discusses, in general terms, the factors that influence educational costs.

\section{Measuring Performance}

One cannot set an educational performance standard without selecting a way to measure performance. ${ }^{1}$ Policy makers may wish to avoid this choice, because selecting a standard is inevitably difficult and controversial; no set of performance standards can capture all aspects 
of learning, and schools may respond to specific standards by "teaching to the test" or otherwise shifting their resources to meet the standard at the expense of other legitimate objectives. Nevertheless, this choice cannot be avoided. Any policy to enhance school performance involves, either explicitly or implicitly, a specific performance measure.

For the most part, the selection of performance measures is based on the judgement of politicians and educational policy officials, perhaps with some input from scholars. The most common measure is a test score, such as an average elementary reading or math score, but the high-school dropout rate also has been used. The use of several measures makes it possible to capture success in a range of educational activities. Policy makers also must indicate the level of performance school districts are expected to meet. For example, school districts might be expected to reach a certain average test score and a certain graduation rate.

We have developed an alternative approach, which selects performance indicators on statistical grounds. This approach determines which performance indicators are valued by voters, as indicated by their correlation with property values and school spending, and results in an index of educational performance (see Duncombe, Ruggiero and Yinger 1996; Duncombe and Yinger 1997). This index is a weighted average of the statistically significant performance indicators, where the weights reflect the value voters place on each indicator. ${ }^{2}$ In the case of New York State, this approach leads to an index based on three performance indicators: the average share of students above the standard reference point on the third and sixth grade PEP tests for math and reading, the share of students who receive a more demanding Regents diploma (which requires passing a series of exams), and the graduation rate. These indicators reflect a wide range of school district activities and reflect success at both the high and low ends of the student performance distribution.

Although these indicators are identified by an objective, statistically based procedure, they do not, of course, summarize all educational activities by a school district. Like all other approaches to measuring 


\section{Metropolitan Studies Program Policy Brief}

performance, this approach makes the problem manageable through simplification. Moreover, this approach results in a performance yardstick, but it cannot determine the point on the yardstick that school districts should be expected to meet. As with other approaches, the selection of the performance target must be based on the judgement of public officials.

\section{Separating Factors In and Outside the Control of School Officials}

Performance standards are intended to boost a school district's incentive to improve its performance. The problem, however, is that actual performance is influenced not only by the decisions of school officials but also by factors outside their control. Thus, some districts find it easy to meet a standard even if they are very inefficient, whereas others find it impossible to meet a standard even if they are more efficient than average. It is neither fair nor effective for a state to reward districts that achieve high performance (or to punish districts that perform poorly) based on factors that are outside their control.

The central issue is that some school districts face relatively high input prices (such as teacher salaries) or relatively harsh educational environments, both of which raise the cost of meeting any educational performance standard. The role of these factors can be summarized with an educational cost index. To ensure fairness across districts and to encourage performance improvements, a performance standard should reward districts that perform well (or punish districts that perform poorly) relative to other districts with the same costs.

\section{The Role of Input Prices}

In the case of education, the most important input is teachers, so in constructing a cost index, it is vital to account for teachers' salaries. Secondary inputs, such as school facilities, also play a role in delivering education, but data on the prices of these inputs are generally not available. 
Duncombe and Yinger

A cost index should measure the impact of factors outside the control of school officials. It is not appropriate, therefore, to directly use actual teachers' salaries in constructing a cost index because those salaries reflect both the generosity of the school district and the underlying labor market conditions. A cost index should reflect the fact that some school districts are located in high-wage labor markets where they must pay high salaries to attract people away from other school districts or away from the private market; and it should reflect the fact that the external conditions in some school districts are so harsh that teachers will not come there without receiving "combat pay"; but it should not reflect the fact that some school district administrators pay higher salaries than necessary to attract their teachers, because they are poor negotiators or for any other reason.

The influence of school officials on teachers' salaries poses a challenge to anyone who wants to construct a cost index. As discussed in a later section, however, well-known statistical procedures can separate the impact of school officials on teachers' salaries from the impact of external factors and produce a cost index based only on factors outside the control of school officials.

\section{The Role of Environmental Factors}

The cost of meeting a performance standard depends on input prices and on the environment in which the relevant services are provided. This section explains the impact of environmental factors on educational costs and shows how it can be estimated using widely available data.

The role of environmental factors, also called fixed inputs, was first identified in the Coleman Report (1966), which showed that a student's performance on standardized tests depended not only on his own characteristics and family background but also on the characteristics and backgrounds of the students in his class. All else equal, for example, a student's performance declines as the share of classmates from poor households increases. This finding translates into a statement about educational costs. If performance declines as student poverty 


\section{Metropolitan Studies Program Policy Brief}

increases, then a district with a high poverty rate cannot achieve the same performance as a district with a low poverty rate without running programs (which, of course, cost money) to offset the impact of poverty.

The important role of environmental factors in educational production has been verified by dozens of studies. A review of many early studies is provided by Hanushek (1986). Good recent studies include Ferguson (1991), Ferguson and Ladd (1996), and Krueger (1997). The study by Ferguson and Ladd, for example, finds that a student's fourth-grade educational performance (on reading and math tests) is affected by, among other things, the share of students receiving a free lunch (a measure of poverty), the share of adults in the district with a college degree, a measure of student turnover, and district enrollment.

Production studies focus on the impact of environmental factors on performance, holding constant inputs selected by the school, such as the student-teacher ratio. These studies imply that costs are higher in school districts with a harsher educational environment, but do not estimate cost differences directly. Moreover, they address a single performance measure at a time and apply to the student or classroom level, not the school district level. Another set of studies shifts the focus to educational costs - and to school districts. These studies determine the extent to which districts with a harsh educational environment, as measured by the characteristics of their students, must pay more to achieve the same performance as other districts. These studies include Bradbury et al. (1984), which looks at all local spending, including spending on education; Ratcliffe, Riddle, and Yinger (1990); Downes and Pogue (1994); Duncombe, Ruggiero, and Yinger (1996); and Duncombe and Yinger (1997). ${ }^{3}$

These studies all demonstrate that a harsher educational environment, as characterized by high rates of poverty and single-parent families, for example, results in a higher cost to obtain any given performance level. In other words, the harsh educational environment in some school districts, particularly big cities, ensures that those districts must spend more than other districts to obtain the same educational performance from their students. 
State educational officials are sometimes aware that environmental factors matter. For example, a report on the the state's schools by New York State Education Department says that "Five indicators, each associated with poor school performance, are useful for identifying students at risk of educational disadvantage: minority racial/ethnic group identity, living in a poverty household, having a poorly educated mother, and having a non-English language background" (The University of the State of New York 1997, p. 3). However, states' performance standards and state aid programs do not take account of these environmental factors in any systematic way. As a result, these programs are, as noted earlier, both unfair and ineffective.

\section{Alternative Methods for Calculating Educational Cost Indexes}

Several methods for calculating educational cost indexes have been proposed by scholars. This section explores the strengths and weaknesses of a few key methods and compares the indexes that result when each method is applied to data for New York State.

\section{Adjusted Input Prices}

Some scholars have proposed that educational costs be measured with an index of input prices, usually just teachers' salaries. Because teachers are by far the most important input in producing education, teachers' salaries do, indeed, have a major impact on educational costs. However, a teacher salary index, by itself, has three major flaws as a measure of educational costs.

First, teachers' salaries reflect differences in teachers' experience and education, which are associated with quality differences across teachers. One cannot claim that a school district has high costs whenever it decides to hire teachers with extensive experience or with graduate degrees. As a result, several scholars (Chambers 1995;

Wendling 1981) have suggested that salaries for teachers of equivalent quality should be compared. 


\section{Metropolitan Studies Program Policy Brief}

Second, as noted earlier, teachers' salaries at a given quality level can be influenced by the decisions of school officials. A cost index based solely on teachers' salaries will provide the misleading impression that generous school districts are forced to pay more than other districts to obtain the same performance when, in fact, their higher spending is entirely of their own making. To solve this problem, scholars (again, see Chambers 1995; Wendling 1981) have suggested the use of regression analysis with teachers' salaries as the dependent variable and both internal and external factors as explanatory variables. In a typical study, the internal factors include teacher experience, education, and certification, as well as the district's salary structure. The key external factors include the wage level in the surrounding labor market and the classroom environment that confronts teachers in each district. The regression results are then used to predict each district's wages on the basis of external factors with internal factors held at the sample average. This approach explicitly recognizes that conditions in some schools are so harsh that teachers must receive "combat pay" to work there. In other words, equally qualified teachers will not come to those schools unless they are paid more that they would be paid at other schools where the private wage scale is the same.

Finally, a teacher salary index ignores the role of the environment on the quantity of resources required. A school district with a harsh educational environment must spend more than other districts to obtain the same performance, even if it has the same teachers' salaries. In other words, environmental factors affect not only the price of inputs but also the quantity of inputs required. To achieve any given performance standard, school districts with a harsh educational environment not only must pay more to attract teachers, but also must hire more teachers (or spend additional money on other educational programs) than schools with an average educational environment. Thus, a cost index based on teachers' salaries, even if it is predicted on the basis of external factors, ignores an important source of variation in educational costs and is inherently unfair to districts with harsh educational environments. 
Duncombe and Yinger

\section{Ad Hoc Cost Adjustments for Environmental Factors}

Many state aid formulas include ad hoc adjustments for environmental factors. States may, for example, compensate districts for a concentration of students with disabilities or whose native language is not English. However, these programs inevitably are ad hoc, with no demonstrated connection between the environmental factors and educational costs.

The 1996 New York State aid programs, for example, include several provisions that could be interpreted as cost adjustments. (See Duncombe and Yinger forthcoming b, for more details.) Operating aid, which is 53 percent of the total, is based on the number of "weighted" pupils in a district. Extra weight goes to pupils in secondary school and pupils with "special education needs," defined as students who score below the minimum competency level on the third and sixth grade reading or math PEP tests. Another program, Extraordinary Needs Aid, gives more aid to districts with lower incomes and higher poverty concentrations. The program provides less than 5 percent of the total aid budget, however, and the formula is not based on any estimate of the relationship between educational costs and poverty.

\section{Comprehensive Cost Indexes with Controls for District Inefficiency}

To move beyond input prices, a cost index must consider the impact of environmental factors on a school districts' costs after accounting for teachers' salaries and for the district's performance. This step requires data on district spending, teachers' salaries, relevant environmental factors, such as the district's poverty rate, and variables to control for a district's educational performance, such as test scores and dropout rates. ${ }^{4}$ Statistical procedures lead to an estimate of the impact of input prices and environmental factors on expenditures, holding student performance levels constant. This approach has now been implemented by Downs and Pogue (1994), Duncombe, Ruggiero, and Yinger (1996), and Duncombe and Yinger (1997). It makes explicit the selection of performance standards and leads directly to an educational 


\section{Metropolitan Studies Program Policy Brief}

cost index, defined as the spending a district is required to make (relative to the average district) to meet any selected performance level.

With this approach, unobserved school district characteristics might affect both school spending (the dependent variable) and measures of performance (explanatory variables). As the above studies all show, this simultaneity problem, along with the one associated with teachers' salaries, can be corrected with a well-known statistical procedure.

One potential problem with this approach is that it might confuse high cost and inefficiency: large districts might not have higher costs, for example, but might instead just be inefficient. In technical terms, ignoring inefficiency could lead to "omitted variable bias" in estimating the effects of environmental factors on costs. One way to deal with this problem is to use a "best-practice" technique to measure, and control for, inefficiency. See Duncombe, Ruggiero, and Yinger (1996) and Duncombe and Yinger (1997, forthcoming b). With this technique, a district is said to be inefficient if it spends more on education than other districts with the same performance and the same educational costs. The degree of inefficiency is measured by the extent of this excess spending. The best-practice variable, and indeed any measure of school district efficiency, could be influenced by unobserved school district characteristics that also influence spending. As a result, this variable, like the performance measures and teachers' salaries, must be treated as "endogenous."

\section{Relationship among Various Approaches}

In this section we will present a comparison of educational cost indexes estimated with the above methods using data from 631 school districts in New York State in 1990-91. The most comprehensive cost index is, as noted earlier, based on a regression analysis of school spending. (See Duncombe and Yinger forthcoming a for details.) The explanatory variables are several performance measures, teachers' salaries, environmental cost factors, and a best-practice control for efficiency. The three performance measures were described earlier. Input prices and the efficiency control are statistically significant with the expected sign. Moreover, four environmental variables play a statistically 
significant role, namely district enrollment, the percentage of children in poverty, the percentage of households headed by a single female, and the percentage of students with limited English proficiency. We find, as do many previous studies, that the impact of district enrollment on costs is roughly U-shaped, with relatively high costs in both the smallest and largest districts. Finally, because expenditures for students with disabilities are so high in some districts, this regression includes a disability variable, namely the percentage of students with a severe handicap, even though it is not significant at conventional levels. ${ }^{5}$

Table 1 describes cost indexes calculated with each method. This table shows how the cost indexes vary by region and type of district, by pupil class size, by income class, and by property value class. The regions in New York are downstate, for the New York City region, and upstate, for the rest of the state. The first column indicates the number of districts in each district class.

Results for the most comprehensive approach, which we believe to be the most accurate, are presented in the second (bolded) column. According to this approach, upstate suburbs have the lowest costs, with an average index of 90.8 , which implies that the average upstate suburb must spend $\$ 0.908$ to achieve the same performance that the average district obtains for $\$ 1.00$. In contrast, New York City, with a cost index of 347.6, must spend almost 3.5 times as much as the average district to achieve the same performance. ${ }^{6}$ Costs are also relatively high in the three large upstate cities (Buffalo, Rochester, and Syracuse), which have an average index of 175.3, and in Yonkers, which has an index of 188.1. The results in this column also reveal that costs are relatively high in the smallest and largest districts and that costs tend to increase with income (and with property value) - except at the bottom of the distribution.

A cost index based on New York State's official weighted pupil measure is presented in the third column of Table 1. This index exhibits little variation across districts; indeed, only one category of district, namely under 100 pupils, has costs more than 3 percent away from the state average. Moreover, the variation that does exist appears 
Metropolitan Studies Program Policy Brief

TABLE 1. Comparison of Education Cost Indexes for New York State School Districts in $1991(n=631)$

\begin{tabular}{|c|c|c|c|c|}
\hline \multirow[b]{2}{*}{$\begin{array}{l}\text { Socio-Economic } \\
\text { Characteristics }\end{array}$} & \multirow[b]{2}{*}{$\begin{array}{c}\text { Number of } \\
\text { Districts }\end{array}$} & \multicolumn{3}{|c|}{ Cost Indexes } \\
\hline & & $\begin{array}{l}\text { Comprehensive } \\
\text { (Controlling for } \\
\text { Inefficiency) }\end{array}$ & $\begin{array}{c}\text { Ad Hoc } \\
\text { (Weighted } \\
\text { Pupils) }\end{array}$ & $\begin{array}{c}\text { Adjusted Input } \\
\text { Prices (Teachers' } \\
\text { Salaries) }\end{array}$ \\
\hline \multicolumn{5}{|l|}{ Region Type } \\
\hline $\begin{array}{l}\text { Downstate Small } \\
\text { Cities }\end{array}$ & 7 & 133.2 & 102.7 & 107.8 \\
\hline Downstate Suburbs & 130 & 110.5 & 101.6 & 102.3 \\
\hline New York City & 1 & 347.6 & 98.1 & 124.2 \\
\hline Yonkers & 1 & 188.1 & 98.7 & 114.4 \\
\hline Upstate Large Cities & 3 & 175.3 & 100.3 & 112.0 \\
\hline Upstate Rural & 212 & 98.5 & 99.9 & 99.1 \\
\hline Upstate Small Cities & 47 & 106.0 & 100.5 & 102.6 \\
\hline Upstate Suburbs & 231 & 90.8 & 99.0 & 98.4 \\
\hline \multicolumn{5}{|c|}{ Number of Pupils per District } \\
\hline Fewer than 100 & 1 & 179.9 & 120.3 & 98.7 \\
\hline 100 to 500 & 61 & 109.1 & 101.2 & 98.8 \\
\hline 500 to 1,000 & 113 & 100.1 & 99.4 & 99.7 \\
\hline 1,000 to 1,500 & 131 & 93.3 & 98.6 & 99.1 \\
\hline 1,500 to 3,000 & 182 & 96.2 & 100.7 & 100.0 \\
\hline 3,000 to 5,000 & 80 & 96.6 & 99.6 & 100.1 \\
\hline 5,000 to 10,000 & 54 & 109.8 & 101.1 & 102.5 \\
\hline 10,000 to 50,000 & 10 & 143.2 & 100.7 & 107.5 \\
\hline More than 50,000 & 1 & 347.6 & 98.1 & 124.2 \\
\hline \multicolumn{5}{|c|}{ District Percentile Rank of Income per Student } \\
\hline Under 10th & 63 & 100.7 & 99.7 & 99.8 \\
\hline 10th to 25 th & 95 & 97.4 & 100.5 & 99.4 \\
\hline 25 th to 50 th & 158 & 96.0 & 99.4 & 99.2 \\
\hline 50th to 75 th & 158 & 98.8 & 99.4 & 99.9 \\
\hline 75th to 90 th & 94 & 105.7 & 99.9 & 101.1 \\
\hline Over 90th & 64 & 107.4 & 102.6 & 101.6 \\
\hline
\end{tabular}

${ }^{\mathrm{a}}$ District cost relative to state average, which is set equal to 100 .

Source: Calculations by authors. 
to miss the high costs in large cities, the U-shaped relationship between costs and enrollment, and the increase in costs with district income and property value. In short, the ad hoc procedures used to determine weighted pupils in New York State bear no systematic relationship to costs estimated with more comprehensive methods.

A cost index based on teachers' salaries is presented in the last column of Table 1. This index adjusts (as do the regression-based indexes) for the fact that higher salaries must be paid to attract teachers of a given quality to harsher educational environments. This approach also picks up the relatively high costs in New York City and in other large cities, but the magnitude of the difference between city and other districts is much smaller. Finally, this approach indicates that costs increase with district income and property value, although the differences along these two dimensions are small. However, this approach fails to pick up the relatively high costs of small districts and finds only modestly higher costs in the large districts than in districts of average size.

In New York State, the correlation between our preferred index and the cost index based on weighted pupils is only 0.12; as shown in Table 1, the weighted-pupil approach has little to do with costs based on a comprehensive analysis. The correlation between our preferred index and the teacher salary cost index is higher, namely 0.85 . Although the teacher salary cost index exhibits relatively little variation compared to our preferred index, it appears that districts with relatively high costs according to one index also tend to have relatively high costs according to the other.

\section{Cost Indexes and State Foundation Formulas}

Educational cost indexes are important largely because they make it possible to design fairer and more effective educational policies. This section explores the link between educational costs and the design of state school aid systems to achieve educational adequacy. Over time, state governments have funded an increasing share of local budgets through state aid. The majority of school aid is distributed through 


\section{Metropolitan Studies Program Policy Brief}

general purpose programs to fund the basic operation of schools. Operating aid is justified primarily on a vertical equity basis-poor school districts and their students should not be penalized for their lack of resources or high needs.

Existing formulas to distribute state aid are seldom explicitly matched with specific equity objectives. However, one common type of aid program, called foundation aid, is well designed to achieve an adequacy objective. We show how to bring educational cost indexes into a foundation aid formula-and what happens when costs are ignored. ${ }^{7}$

\section{How to Include Cost Indexes in a Foundation Formula}

A large majority of states use some form of a foundation aid, but they all use spending as a measure of "performance," and therefore do not bring many districts up to a minimal performance standard defined on the basis of test scores or other indicators. This need not be the case; cost indexes make it possible to design a foundation formula that brings all districts up to a performance standard (see Ladd and Yinger, 1994; Duncombe and Yinger, 1997).

A foundation plan is designed to bring all districts up to a minimum spending level per pupil if they levy a certain tax rate. The traditional expenditure-based foundation formula provides aid $(A)$ to districts based on the following distribution formula:

$A=E^{*}-t^{*} V$

where $E^{*}$ is the expenditure standard, $t^{*}$ is the state set minimum tax rate, and $V$ represents property value per pupil. A district receives state aid under a foundation formula if the revenue it can raise at the state-set tax rate, $t^{*}$, is less than the foundation level of spending, $E^{*}$. Districts wealthy enough to raise the required revenue by themselves at rate $t^{*}$ receive no aid from the state. A foundation grant usually is accompanied by a requirement that each district levy a tax rate of at least $t^{*}$; otherwise, some districts might not provide the minimum acceptable spending level, $E^{*} .8$ 
Duncombe and Yinger

Because it does not systematically account for cost differences across districts, an expenditure-based foundation plan does not bring all districts up to a minimum performance level; districts with relatively high costs cannot reach the standard unless they set a tax rate above $t^{*}$. To switch from spending to performance, one must incorporate an educational cost index into the aid formula. To bring all districts up to a performance standard, denoted by $S^{*}$, at an acceptable tax burden on their residents, the performance-based foundation formula should be

$A=S^{*} C-t^{*} V$

where $C$ is the amount a district must spend to obtain one unit of $S^{*}$. The amount of aid a district receives equals the spending required to reach $S^{*}$ minus the amount of revenue it can raise at $t^{*}$. A performance-based formula ensures that all districts have enough funds to meet this performance standard given their costs, again assuming (and usually requiring) that they levy a minimum tax rate.

Both types of foundation formulas are based on the assumption that all districts are perfectly efficient. Because some districts are inefficient, even the performance-based formula will not, in practice, bring all districts up to the foundation level (and implicit performance standard) even with a required minimum tax rate. As a result, it seems reasonable to design a foundation formula so that every district will have enough revenue to achieve the foundation performance level at some efficiency level, say the 75th percentile of the current bestpractice efficiency level, which we call the baseline efficiency level. To adjust the aid formula for less-than-perfect efficiency, we divide $S^{*} C$ by the baseline efficiency level, which results in the required expenditures to achieve $S^{*}$ at baseline efficiency. If the district's efficiency falls short of this level, it will not achieve the foundation level of performance unless its tax rate is above $t^{*}$.

\section{Simulating the Effect of a Performance-Based Aid Program}

Using data from New York State school districts, excluding New York City (which otherwise would dominate the aid program), ${ }^{9}$ Duncombe 


\section{Metropolitan Studies Program Policy Brief}

and Yinger (1997) simulate the effect of different aid systems on student performance. These simulations employ not only the performance and cost indexes discussed earlier, but also analyses of voter demand for educational performance and of the determinants of school district efficiency, which are not discussed in this policy brief.

Figure 1 reports aid distribution in New York State in 1991 under three different aid systems. The first bar indicates actual aid in 1991, which includes several small lump-sum programs plus a plan similar to a foundation plan with the minimum expenditure level set at approximately the 25th percentile of the 1991 expenditure distribution. This plan includes two provisions that reduce its effectiveness: a minimum level of aid and a "hold harmless" provision that prevents a district's aid from declining. The second bar in Figure 1 presents estimated aid levels with an expenditure-based foundation plan, and the third bar presents estimated aid levels with a performance-based foundation plan that has an efficiency baseline.

A performance-based aid system targets aid to the districts with the poorest fiscal health, as defined by the relationship between district wealth and educational costs. Large city districts, which have below average property wealth and costs well above the state average, would receive a significant increase in aid compared to the actual aid received by these districts in 1991. Aid to the three large cities would go up by 2.5 times with a 25 th percentile performance standard (top panel in Figure 1), and would increase by over 3.5 times when the standard is set at the 75th percentile (lower panel). The higher aid would be financed by small declines in aid to rural districts and a 20 to 40 percent drop in aid to suburban districts. By contrast, expenditurebased foundation grants provide only modest increases in aid (15 to 30 percent) to large cities, and small cuts aid to suburbs ( 2 to 4 percent). A traditional formula does not compensate large cities for their higher costs.

Figure 2 shows the average performance, as measured by the performance index described earlier, in each class of district under the three aid systems. All the aid programs have the same overall state aid 
budget and the two foundation grants impose a minimum-tax-rate requirement. Each type of aid system (a column) is examined for two different performance standards or foundation levels (the panels), namely the 25th and 75th percentiles of the 1991 performance distribution in New York State, as measured by the performance index.

The first bar in Figure 2 indicates performance under the actual 1991 aid system, and the second and third bars represent the expenditurebased and performance-based foundation grants, respectively. The performance increases above existing levels under a performancebased formula are most dramatic for large, upstate central cities. The average performance for these three cities goes up 72 percent with a low standard (top panel) and by 2.5 times with the high standard (lower panel). The new performance levels fall below the target $S^{*}$ because the efficiency level in these districts falls below the baseline level. This performance-based foundation plan also boosts performance in all other classes of district, although not by such dramatic amounts. ${ }^{10}$

Because the implicit expenditure standard in the current New York State aid plan is set at about the 25th percentile of the current expenditure distribution, a comparison of current aid (bar 1) with a "pure" expenditure-based foundation plan (bar 2) largely reflects the impact of eliminating hold-harmless and minimum-aid provisions and pooling all lump-sum aid into a foundation formula (upper panel). These steps would only modestly increase performance in large cities and most types of districts. Moving to a higher standard under an expenditure-based foundation would result in substantial increases in performance in all types of districts except large cities. All the expenditure-based foundation plans leave large cities far short of any performance target. In fact, the most generous such plan, in the lower panel of Figure 2, leaves large cities at a performance level well below the 25th percentile of the current distribution. ${ }^{11}$ Expenditure-based foundation plans, which are used in most states, leave many highcost districts short of even a minimal performance standard! 
Metropolitan Studies Program Policy Brief
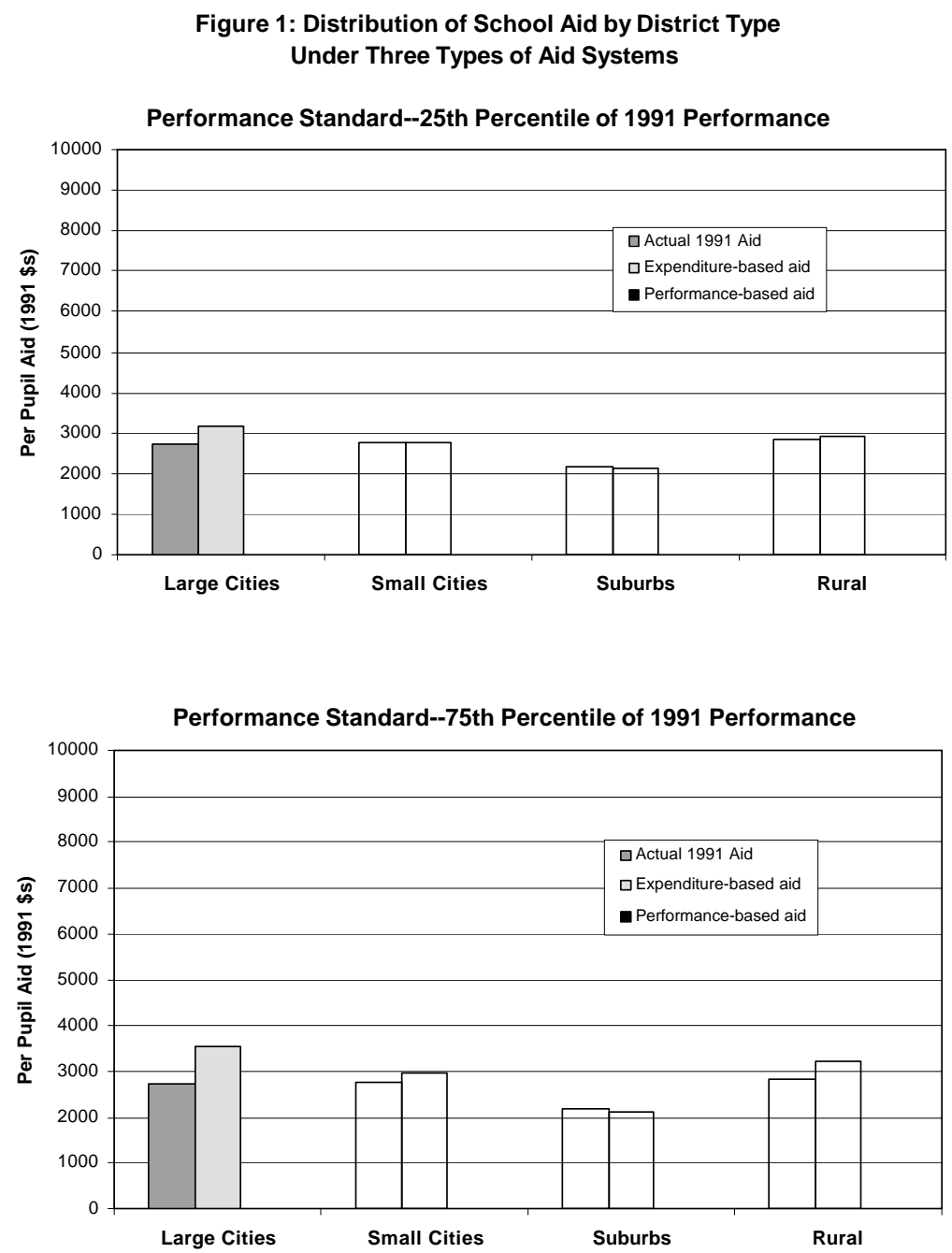
Duncombe and Yinger

\section{Conclusions}

An extensive literature establishes that both school district and student performance depend not only on factors that school officials control, such as the student/teacher ratio, but also on factors that are outside their control, including input prices, such as regional wage rates, and environmental factors, such as concentrated poverty. It follows directly that the cost of education is not the same in every district, with higher costs in districts in higher-wage labor markets or with a harsher educational environment. A shift to educational performance standards, whether these standards are simply targets or are imbedded in a foundation aid program, can be neither fair nor effective unless it recognizes this variation in the cost of education. This shift cannot be fair because it penalizes districts that, through no fault of their own, face harsh educational environments, and it cannot be effective because it hands out rewards and punishments that are not related to the contributions of school personnel.

Scholars have identified a variety of methods for measuring the cost of education, all of which have limitations. The simplest reasonable methods, which are indexes of teachers salaries predicted on the basis of conditions in the local labor market and in a district's schools, fail to recognize that districts with a relatively harsh educational environment must hire more teachers (or purchase more of other inputs) than other districts to achieve the same performance. The most comprehensive methods, which recognize the role of environmental factors and control for school district efficiency, involve some complex, hard-to-explain steps. Nevertheless, the literature demonstrates that cost variation across schools is very large and cannot be ignored. Policy makers and scholars need to continue the search for sensible, practical ways to measure educational costs and incorporate them into performancebased educational policies. 
Metropolitan Studies Program Policy Brief

Figure 2: Distribution of Student Performance (composite index) by District Type Under Three Types of Aid Systems

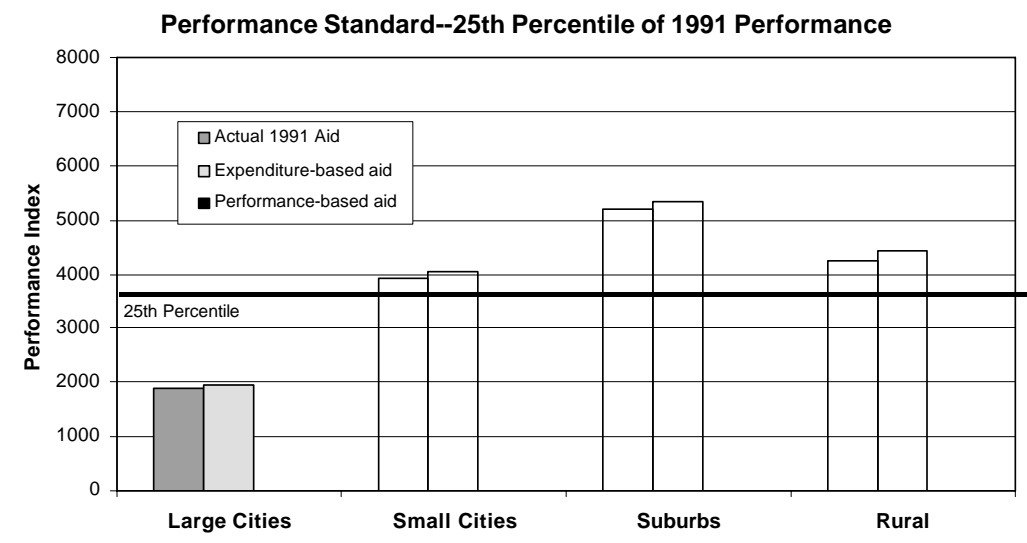

Performance Standard--75th Percentile of 1991 Performance

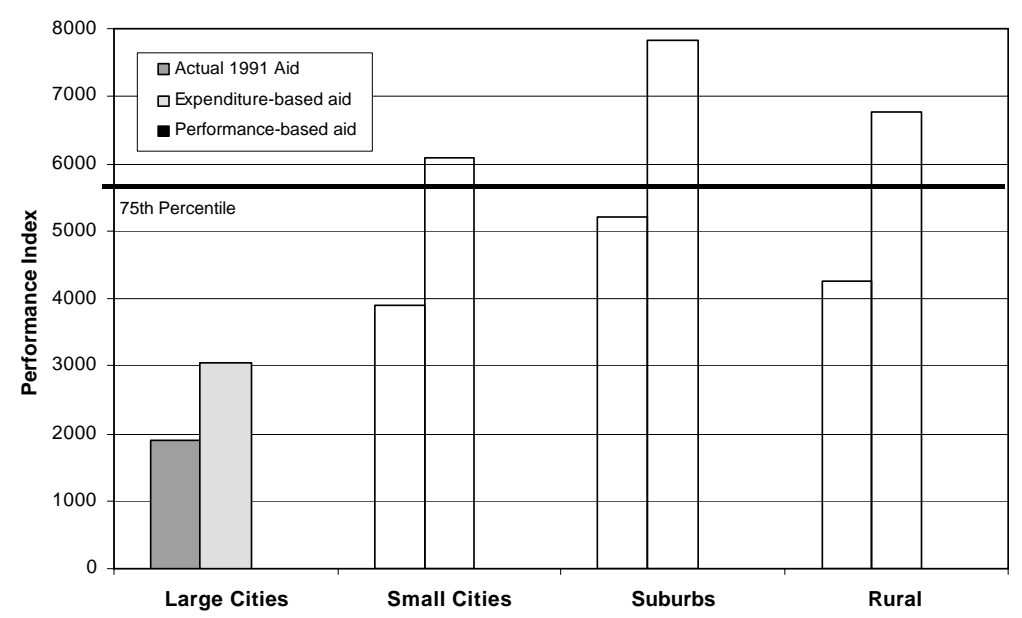


Duncombe and Yinger

\section{References}

Bradbury, Katharine L., Helen F. Ladd, Mark Perrault, Andrew Reschovsky, and John Yinger. 1984. "State Aid to Offset Fiscal Disparities across Communities." National Tax Journal 37 (June): 151-170.

Bradford, David, Robert Malt and Wallace Oates. 1969. "The Rising Cost of Local Public Services: Some Evidence and Reflections." National Tax Journal 22 (June): 185-202.

Chaikind, Stephen, Louis C. Danielson, and Marsha L. Brauen. 1993. "What Do We Know About the Costs of Special Education? A Selected Review." The Journal of Special Education 26, 4: 344370 .

Chambers, Jay. 1995. "Public School Teacher Cost Differences Across the United States: Introduction to a Teacher Cost Index (TCI)." In William J. Fowler, Jr. (ed.), Developments in School Finance, 1995. Washington, DC: National Center for Education Statistics, pp. 21-32.

Clotfelter, Charles and Helen F. Ladd. 1996. "Recognizing and Rewarding Success in Public Schools." In H. F. Ladd (ed.), Holding Schools Accountable: Performance-Based Reform in Education. Washington, D.C.: The Brookings Institution, pp. 2364.

Clune, William. 1994. "The Shift from Equity to Adequacy in School Finance.” Educational Policy 8 (December): 376-394.

Coleman, James. 1966. Equality of Educational Opportunity. Washington, DC: U.S. Government Printing Office. 
Metropolitan Studies Program Policy Brief

Downes, Thomas and Therese McGuire. 1994. "Alternative Solutions to Illinois' School Finance Dilemma: A Policy Brief." State Tax Notes, February 14: 415-419.

Downes, Thomas and Thomas Pogue. 1994. "Adjusting School Aid Formulas for the Higher Cost of Educating Disadvantaged Students," National Tax Journal, 47: 89-110.

Duncombe, William, John Ruggiero, and John Yinger. 1996. "Alternative Approaches to Measuring the Cost of Education." In H. F. Ladd (ed.), Holding Schools Accountable: PerformanceBased Reform in Education. Washington, D.C.: The Brookings Institution, pp. 327-356.

Duncombe, William and John Yinger. Forthcoming a. "An Analysis of Two Educational Policy Changes in New York: Performance Standards and Property Tax Relief." To appear in a conference volume published by the New York State Board of Regents.

Duncombe, William and John Yinger. Forthcoming b. "School Finance Reform: Aid Formulas and Equity Objectives." National Tax Journal. Forthcoming.

Duncombe, William and John Yinger. 1997. "Why Is It So Hard to Help Central City Schools?” Journal of Policy Analysis and Management 16 (Winter): 85-113.

Ferguson, Ronald. 1991. "Paying for Public Education: New Evidence on How and Why Money Matters." Harvard Journal on Legislation 28: 465-498.

Ferguson, Ronald and Helen F. Ladd. 1996. “Additional Evidence on How and Why Money Matters: A Production Function Analysis of Alabama Schools." In H.F. Ladd (ed.), Holding Schools Accountable: Performance-Based Reform in Education. Washington, DC: The Brookings Institution. 
Fuhrman, Susan, Richard Elmore, and Diane Massell. 1993. "School Reform in the United States: Putting It into Context." In S. Jacobson and R. Berne (eds.) Reforming Education: The Emerging Systematic Approach., Thousand Oaks, CA: Corwin Press, pp. 327.

Hanushek, Eric. 1986. "The Economics of Schooling: Production and Efficiency in Public Schools." Journal of Economic Literature, 24: 1141-1177.

Kreuger, Alan B. 1997. "Empirical Estimates of Education Production Functions.” Industrial Relations Section Working Paper \#379. Princeton University, Princeton, N.J.

Ladd, Helen and John Yinger. 1994. "The Case for Equalizing Aid." National Tax Journal 47 (March): 211-224.

Linn. R. L. 1993. "Educational Assessment: Expanded Expectations and Challenges." Educational Evaluation \& Policy Analysis 15, 1: 1-16.

Miner, Jerry. 1991. “A Decade of New York State Aid to Local Schools," Metropolitan Studies Program Occasional Paper No. 141, Center for Policy Research, The Maxwell School. Syracuse, NY: Syracuse University.

Ratcliffe, Kerri, Bruce Riddle, and John Yinger. 1990. "The Fiscal Condition of School Districts in Nebraska: Is Small Beautiful?" Economics of Education Review, 9: 81-99.

Steinberg, Jacques. 1998. "Underachieving Schools Are Shamed Into Improvement." The New York Times, January 7, 1998.

Underwood, Julie. 1995. "School Finance Adequacy as Vertical Equity." University of Michigan Journal of Law 28: 493. 
Metropolitan Studies Program Policy Brief

The University of the State of New York and The State Education Department. 1996. State Aid to Schools: A Primer. Albany: SUNY.

1997. New York: The State of Learning, Statewide Profile of the Educational System. Albany: SUNY.

Wendling, Wayne. 1981. "The Cost of Education Index: Measurement of Price Differences of Education Personnel among New York State School Districts." Journal of Education Finance 6 (Spring): 485-504. 